\title{
Alloantigen-specific Allogeneic Type 1 Regulatory T Cells T-allo10
}

National Cancer Institute

\section{Source}

National Cancer Institute. Alloantigen-specific Allogeneic Type 1 Regulatory T Cells Tallo10. NCl Thesaurus. Code C134838.

A preparation of allogeneic CD4+ cells that were ex vivo stimulated with alloantigens, which involves exposing the cells to host antigen-presenting cells (APCs), in the presence of the immunomodulatory cytokine interleukin-10 (IL-10), with potential to prevent graftversus-host disease (GvHD). The stimulation of the CD4+ cells by exposure to alloantigens plus IL-10 induces the differentiation of alloantigen-specific type $1 \mathrm{~T}$ regulatory (TR1) cells, which are hyporesponsive to the alloantigens. Upon infusion of Tallo10 and prior to donor hematopoietic stem cell transplantation (HSCT), the alloantigen-specific type 1 regulatory T-cells are tolerant to the alloantigens and suppress alloreactive immune responses by donor CD4+ and CD8+ T-cells. This may ultimately prevent GVHD. IL-10 plays a key role in controlling inflammation, downregulating immune responses, and inducing immunological tolerance. IL-10 induces both a long lasting antigen specific T-cell anergy and the differentiation of TR1 cells. 